\title{
Strip Tillage and Compost Influence Carrot Quality, Yield, and Net Returns
}

\author{
Daniel C. Brainard ${ }^{\mathbf{1}}$ and D. Corey Noyes \\ Department of Horticulture, Michigan State University, A440A Plant and \\ Soil Sciences Building, East Lansing, MI 48824
}

Additional index words. weed management, partial budget analysis, profitability

\begin{abstract}
Management practices that build soil organic matter-including reduced tillage, cover cropping, and compost applications - may be useful for protecting vulnerable crops from extreme weather events, reducing energy costs, and suppressing pests in carrot (Daucus carota subsp. sativa) production systems. The primary objective of this research was to assess the effects of strip tillage, compost, and carrot cultivar on carrot quality, yield, and profitability. An important secondary objective was to evaluate the impact of tillage and compost on establishment of important weeds in carrot systems - including two species that have developed resistance to linuron: Powell amaranth (Amaranthus powellii) and common purslane (Portulaca oleracea). Field experiments were conducted in 2009 and 2010 comparing conventional tillage (CT) to strip tillage (ST) under two rates of mature

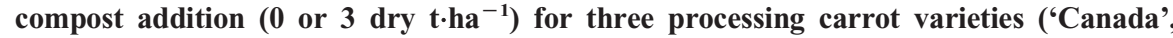
'Finley', and 'Recoleta'). In the ST system, a pre-established barley cover crop was left to grow as a windbreak between crop rows until carrots were established. Partial budget analysis was used to estimate net returns associated with all treatments. Compared with CT, the ST system resulted in 1) either equivalent or greater (2010, Finley cultivar) total carrot yields and net returns; and 2) either equivalent or lower summer annual weed densities. Addition of compost resulted in equivalent (2010) or higher (2009) carrot yields and gross returns but did not affect net returns as a result of the increased costs associated with compost application. Compost reduced the density of common purslane in 2009 but resulted in a threefold increase in the density of Powell amaranth in 2010. Our results demonstrate that both ST and compost applications are potentially valuable tools for improving the profitability of carrot production systems. Future research examining the mechanistic basis for compost and tillage effects on carrots and weeds as well as the longterm effects of these practices on profitability of rotational crops would be helpful for optimizing their use in vegetable production systems.
\end{abstract}

Management practices that build soil organic matter (SOM) are valuable for improving soil water-holding capacity, nutrient retention, aeration, and infiltration rates (Magdoff and van Es, 2000). For carrots (Daucus carota subsp. sativa), these functions are particularly important, because fluctuations in soil moisture and nutrient availability can have negative impacts on carrot quality and yield (Batra and Kalloo, 1990; Bienz, 1965). Increased biological activity associated with SOM may

Received for publication 19 Mar. 2012. Accepted for publication 14 June 2012.

Funding for this research was provided by MAES Project GREEEN; the Michigan Vegetable Council; the Michigan Carrot Committee; and the Michigan Department of Agriculture USDA Specialty Crop Block Grant Program.

We thank William Chase and Bruce Sackett for technical assistance with field trials and Norm Myers for his insights and for facilitating grower collaborations. We also acknowledge the support of our grower-cooperators Rick and Tom Oomen (Oomen Farms); Ralph and Ken Oomen (Oomen Brothers Farm); and Gerald and Ryan Malburg (Malburg Farms) for their valuable advice and input. Previous versions of this article benefited from the editorial comments of Erin Haramoto and Carolyn Lowry.

${ }^{1}$ To whom reprint requests should be addressed; e-mail brainar9@msu.edu. also reduce the prevalence of plant parasitic nematodes and fungal pathogens, both important factors reducing quality and yield in carrot production (Abawi and Widmer, 2000; Widmer et al., 2002).

Vegetable growers can increase SOM by adding organic amendments including compost and cover crops and by minimizing SOM losses through reduced tillage practices (Magdoff and van Es, 2000). Although organic matter inputs are common in vegetable production systems, adoption of reduced tillage practices has been limited. Indeed, most vegetable production systems till extensively to suppress weeds, to incorporate residues, and to promote mineralization and soil-warming. For small seeded crops like carrots, tillage is critical for creating the fine seedbed necessary for good stand establishment. Although elimination of tillage may not be practical or desirable in many vegetable crops, the extent of tillage can be reduced using hybrid tillage systems including ST (Luna et al., 2012). Under ST, a narrow band is tilled where the crop is to be planted, leaving an undisturbed strip between crop rows to protect and improve soils. Strip tillage can also reduce energy costs and equipment wear by reducing the number of tractor passes and horsepower required to prepare fields (Luna and Staben, 2002).
Strip tillage in combination with cover crops provides a valuable windbreak for carrot producers. Currently, several growers in western Michigan use pre-established cover crops in combination with ST primarily to reduce the risk of stand loss of vulnerable carrot seedlings resulting from wind and rain early in the growing season (personal observation). In this system, pre-established wheat or barley is allowed to grow in the nontilled between-row strips until carrot seedlings reach the two- to three-leaf stage and then is killed with standard post-emergence grass herbicides.

Strip tillage has been used successfully in several vegetable crops including sweet corn, snap beans, and cabbage (Luna et al., 2012; Mochizuki et al., 2007). However, to our knowledge, the impact of ST on carrots has not been previously evaluated. Holmstrom et al. (2008) evaluated the potential for soil conservation practices including full-width reduced tillage and mulches for Canadian carrot production but found that these practices resulted in poor seedling establishment or increases in parasitic nematodes.

Despite the potential value of ST and compost for vegetables, adoption has been slowed in part by uncertainties about the effects of these practices on crop establishment and yield and concerns about the potential difficulty in managing weeds when tillage is reduced (Luna et al., 2012). In some cases, the prevalence of perennial and winter annual weeds increases when tillage is no longer used to physically disturb soil (Brainard et al., 2012; Luna and Staben, 2002). On the other hand, reduced tillage systems may reduce the prevalence of certain weed species through a variety of mechanisms, including reduced stimulation of seed germination, increased rates of seed predation and decay, and through the suppressive effects of cover crop residues, which remain on the soil surface under reduced tillage systems (Liebman and Mohler, 2001; Luna et al., 2012; Teasdale, 1998). Evaluation of the impact of management practices on weeds is particularly important in carrot production as a result of the poor competitiveness of carrots with weeds; the limited number of registered broadleaf herbicides available for carrot growers; and the development of herbicide-resistant weeds in carrot production systems including linuronresistant common purslane (Portulaca oleracea) (Masabni and Zandstra, 1999) and Powell amaranth (Amaranthus powellii) (McNaughton et al., 2005).

The primary objective of this research was to assess the effects of ST and compost on establishment, quality, yield, and profitability of three processing carrot varieties. Secondary objectives included evaluating the impacts of tillage and compost on weed populations. We hypothesized that ST and compost would maintain or improve carrot yield and profitability but that these effects would differ by cultivar. We further hypothesized that ST and compost would influence the density of important weeds in carrot production systems. 


\section{Methods}

Field trials. Field trials were conducted in 2009 and in 2010 examining the effects of tillage (conventional vs. strip till), compost (none vs. 3 dry t.ha ${ }^{-1}$ ), and carrot cultivar (Canada, Finley, and Recoleta) on 1) carrot establishment, quality, and yield; 2) weed density and composition; and 3) gross and net returns. The experimental plots were arranged in a split-split plot design with tillage as the main plot factor, compost as the subplot factor, and carrot cultivar as the sub-subplot factor. Main plots measured $6.1 \mathrm{~m} \times 24.4 \mathrm{~m}$, subplots measured $6.1 \times 12.2 \mathrm{~m}$, and subsubplots measured $1.8 \times 12.2 \mathrm{~m}$. Sub-subplots consisted of three rows of carrots on a single bed with yield and quality data taken from $9.1 \mathrm{~m}$ of the center row. In 2009, the experimental site was located at the Michigan State University Horticultural Research and Teaching Center in Holt, MI, on a Spinks loamysand with $\mathrm{pH}$ 6.5. In 2010, the experiment was conducted at the MSU Montcalm Potato Research Station in Entrican, MI, on a Montcalm/McBride loamy-sand with $\mathrm{pH}$ 6.3.

The timing of major field operations and data collection are summarized in Table 1. In ST treatments, a barley cover crop was drilled at $107 \mathrm{~kg} \cdot \mathrm{ha}^{-1}$ on $11 \mathrm{Apr} .2009$ and $15 \mathrm{Apr}$. 2010. Fertilization was based on soil test results according to standard recommendations for carrots (Warncke et al., 2004); all treatments received $392 \mathrm{~kg} \cdot \mathrm{ha}^{-1}$ of $19 \mathrm{~N}$ 19P-19K fertilizer before tillage in early May followed by two side-dress applications of $97 \mathrm{~kg} \cdot \mathrm{ha}^{-1}$ of urea $(46 \mathrm{~N}-0 \mathrm{P}-0 \mathrm{~K})$ in June and July. Compost treatments received in addition to the fertilizer, $3 \mathrm{t} \cdot \mathrm{ha}^{-1}$ (dry weight basis) of cow manure-based compost ("Dairy Doo"; Morgan's Compost, Sears, MI) applied before tillage in early May (Table 1). Each year, a new batch was purchased. Batches did not differ significantly in their nutrient composition, so mean data for both years are presented in Table 1 . At 3 dry $\mathrm{t} \cdot \mathrm{ha}^{-1}$, nutrient contributions from compost were $\approx 36 \mathrm{~kg} \mathrm{ni-}$ trogen $(\mathrm{N}) / \mathrm{ha}, 24 \mathrm{~kg}$ phosphorus $(\mathrm{P}) / \mathrm{ha}, 41 \mathrm{~kg}$ potassium $(\mathrm{K}) / \mathrm{ha}, 95 \mathrm{~kg}$ calcium $(\mathrm{Ca}) / \mathrm{ha}$, and $20 \mathrm{~kg}$ magnesium $(\mathrm{Mg}) / \mathrm{ha}$ (Table 2). For compost, it is typically assumed that between $10 \%$ and $50 \%$ of $\mathrm{N}$ is available in the first season after application (Sanchez and Richard, 2009). Therefore, available N from compost was likely between 3.6 and 18 $\mathrm{kg} \mathrm{N} / \mathrm{ha}$.

On 8 May 2009 and 4 May 2010, strips were established $46 \mathrm{~cm}$ apart in three-row beds using an Unverferth 120 zone builder set at $37-\mathrm{cm}$ depth followed by a $24-\mathrm{cm}$ wide rototiller set at $\approx 5 \mathrm{~cm}$ depth. CT was accomplished with a chisel plow followed by two passes with a field cultivator. Before tillage, the barley cover crop was 5 to $7 \mathrm{~cm}$ tall. Tillage effectively killed barley in CT treatments and in the in-row area of ST treatments. Barley in the between-row zone of ST treatments was left undisturbed as a windbreak until the time of clethodim application 4 to 5 weeks after planting. Carrots were planted on the same day as tillage at a population of $\approx 500,000$ seeds/ha using a three-row MaterMac vacuum seeder. Seeds were sown in three rows per bed centered on the ST zones ( $46 \mathrm{~cm}$ between rows) with $61 \mathrm{~cm}$ between outer rows of adjacent beds.

Herbicide treatments followed standard grower practices and included a preemergence application of s-metolachlor $(0.27 \mathrm{~kg}$ a.i./ha) and linuron (0.56 kg a.i./ha) applied 1 to 2 weeks after carrot planting and postemergence applications of clethodim $(0.14 \mathrm{~kg}$ a.i./ha) applied at 4 to 5 weeks after planting and linuron $(0.56 \mathrm{~kg}$ a.i./ha) applied at 5 to 6 weeks after planting. The clethodim application was used to kill annual grasses (mostly large crabgrass) in all treatments as well as the barley cover crop in ST treatments. At the time of clethodim application, barley windbreaks had reached $\approx 30 \mathrm{~cm}$ tall in 2009 and $20 \mathrm{~cm}$ tall in 2010. All herbicide applications were made at $234 \mathrm{~L} \cdot \mathrm{ha}{ }^{-1}$ at $207 \mathrm{kPa}$ with a $\mathrm{CO}_{2}$ backpack sprayer equipped with Teejet VS8002 nozzles.

Weed density by species was assessed in two $0.25-\mathrm{m}^{2}$ quadrats per plot in both in-row and between-row environments on 26 June 2009 and 17 June 2010. To assess the number of weeds escaping herbicide treatments, additional weed counts by species were conducted on 18 July 2009 and on 12 July 2010. Because escaped weed densities at this time were low, counts were conducted over the entire subplot area. In addition to standard herbicide practices, hand-weeding was done after the second weed count to remove large weeds in all treatments. Such hand-weeding is common in commercial carrot production in Michigan.

In September, carrot roots were harvested from a 9.1-m section from the center row of each sub-subplot, separated into categories (defect-free, cracked, forked, or undersized), and weighed. Carrots were considered defective ("culls") if cracks exceeded $2.5 \mathrm{~cm}$ in length, forks exceeded two per root, and undersized if root diameter was less than $3.5 \mathrm{~cm}$. These criteria were established in consultation with growers based on their experience in the processing market. In addition, a random subsample of five defectfree carrots per plot-including both roots and shoots - was removed, separated into shoots and roots, and weighed. Roots from this subsample were assessed for soluble solid content by extracting sap from a composite of root sections and measuring the refractive index (RI) with an Atago ${ }^{\circledR}$ PAL-1 digital handheld refractometer. This device reports RI readings in degrees Brix based on the relationship between RI and the sucrose concentration $(\% \mathrm{w} / \mathrm{w})$ of a pure sucrose solution at $20{ }^{\circ} \mathrm{C}$. Brix measurements reflect not only sucrose, but also other sugars including glucose as well as other soluble solids that may have little impact on sweetness (Zhu et al., 1992). Shoots and roots were then dried and weighed and the root:shoot ratio (RSR) calculated based on dry weights.

Economic analysis. The net return for each treatment was estimated using partial budget analysis. Gross returns were calculated
Table 1. Schedule of major field operations and data collection events, 2009 and 2010.

\begin{tabular}{lrr}
\hline & \multicolumn{2}{c}{ Date } \\
\cline { 2 - 3 } Event & 2009 & 2010 \\
\hline Barley planted & $11 \mathrm{Apr}$. & $15 \mathrm{Apr}$. \\
Fertilizer/compost applied & $4 \mathrm{May}$ & 3 May \\
Tillage & $8 \mathrm{May}$ & 4 May \\
Carrot planting & $8 \mathrm{May}$ & $6 \mathrm{May}$ \\
Lorox/dual application & 18 May & 18 May \\
Carrot seedling counts & 27 May & 25 May \\
Select application & 15 June & 3 June \\
Carrot seedling counts & 11 June & 17 June \\
Weed count and removal & 26 June & 17 June \\
Lorox application (2) & 9 July & 17 June \\
Urea sidedress (1) & 26 June & 21 June \\
Weed count and removal & 18 July & 12 July \\
Urea sidedress (2) & 25 July & 27 July \\
Harvest & 24 Sept. & 8 Sept. \\
\hline
\end{tabular}

Table 2. Compost chemical characteristics and rates. $^{2}$

\begin{tabular}{lcc}
\hline & \multicolumn{2}{c}{ Compost } \\
\cline { 2 - 3 } Nutrient & Content (\%) & Rate $^{\mathrm{y}}\left(\mathrm{kg} \cdot \mathrm{ha}^{-1}\right)$ \\
\hline Nitrogen $^{\mathrm{x}}$ & 1.22 & 36 \\
Phosphorus $_{\text {Potassium }}$ & 0.82 & 24 \\
Calcium & 1.37 & 41 \\
Magnesium & 3.21 & 95 \\
Sodium & 0.68 & 20 \\
Sulfur & 0.24 & 7 \\
\end{tabular}

${ }^{\mathrm{z}}$ Data are average of 2009 and 2010.

${ }^{\mathrm{y}}$ Rate is based on $3 \mathrm{t} \cdot \mathrm{ha}^{-1}$ dry compost rate.

${ }^{\mathrm{x}}$ Total nitrogen; available nitrogen is usually $10 \%$ to $50 \%$ of total.

as the weight of defect-free carrots times the price for defect free carrots plus the weight of cull carrots times the price for cull carrots. Net returns were calculated by subtracting total variable costs from gross returns. Processing carrot prices were based on 3-year average value for Michigan processing carrots from 2007-2009 (ERS/USDA, 2011) as well as available information on deductions for cull carrots (forked or cracked carrots). Deductions for cull carrots change based largely on the market for deer bait with the price for culls reaching up to $80 \%$ of the processing market price (Beversluis, 2008). Given the uncertainty in this market, the impact of a range of price assumptions on gross and net returns for all treatments was examined with a baseline assumption that the effective price for cull carrots was $50 \%$ of the processor price. Carrot production costs other than those related to compost or tillage were based on data compiled by Dartt et al. (2002) adjusted for inflation using the agricultural input price index. These costs were adjusted based on actual practices used that differed from those assumed by Dartt et al. (2002). Compost cost estimates were based on the actual price paid per tonne plus 1) estimated transport costs from Sears (Morgan Compost) to Hart, MI (location of several major processing carrot producers); and 2) custom work rate estimates for spreading compost (manure) from Stein (2011). Tillage cost estimates were based on custom machine and work rate estimates for Michigan for 
chisel plowing, disking, field cultivating, and ST (Stein, 2011).

Statistical analysis. The fixed effects of tillage, compost, and carrot cultivar on carrot density, yield, quality characteristics, and gross and net returns were analyzed using PROC MIXED procedures in SAS (SAS Institute, 2009). For weed counts, data were collected on the subplot level, so only the fixed effects of tillage and compost were assessed. To improve assumptions of normality and homogeneity, carrot defect percentage data were square root-transformed and weed density data log-transformed. All other responses did not require transformation. Differences between treatments were evaluated by pdiff and slice LSMEANS options in the PROC MIXED procedure. In most cases, significant interactions of fixed effects with year were detected, so analyses were conducted separately by year. However, for responses for which no significant year interactions were detected, including carrot root-shoot ratio and Brix - combined data for both years are presented.

\section{Results}

Weather. Temperature and rainfall conditions were very different in 2009 and 2010 (Table 3). In particular, mean temperatures in July and August were $2.6{ }^{\circ} \mathrm{C}$ higher in 2010 compared with 2009 . Conditions were also drier in 2010 compared with 2009 with $165 \mathrm{~mm}$ less rainfall falling during the period of carrot growth.

Carrot establishment and mortality. In 2009, neither tillage nor compost had any detectable effect on seedling density in May, June, or September (Table 4). Initial densities also did not differ by cultivar. However, higher seedling mortality resulted in lower final carrot number for the cultivar Finley (11 carrots $/ \mathrm{m})$ compared with Canada (14.4 carrots $/ \mathrm{m})$.

In 2010, final carrot density was influenced by cultivar and tillage but not by compost (Table 4). In particular, the ST system resulted in higher final carrot densities than CT $(P<$ $0.10)$ attributable primarily to changes occurring between June and September (Table 4). The mechanism by which ST might have resulted in increases in carrot seedlings during this period is not clear. However, it should be noted that in the ST system, standing residue of the herbicide-killed barley cover crop persists between crop rows and likely

Table 3. Average temperature and cumulative rainfall 2009 (Holt) and 2010 (Entrican).

\begin{tabular}{lrrrrr}
\hline & \multicolumn{2}{c}{$\begin{array}{c}\text { Temperature } \\
\left({ }^{\circ} \mathrm{C}\right)\end{array}$} & & \multicolumn{2}{c}{$\begin{array}{c}\text { Rainfall } \\
(\mathrm{mm})\end{array}$} \\
\cline { 2 - 3 } Month & 2009 & 2010 & & 2009 & 2010 \\
\hline April & 8.8 & 10.3 & & 76.5 & 40.4 \\
May & 14.2 & 15.2 & & 165.1 & 93.5 \\
June & 19.1 & 19.3 & & 109.0 & 81.5 \\
July & 19.1 & 22.6 & & 126.2 & 54.4 \\
August & 20.2 & 22.0 & & 60.7 & 66.8 \\
September & 17.1 & 15.1 & & 104.7 & 47.8 \\
May to June & 16.6 & 17.2 & & 274.1 & 175.0 \\
July to August & 19.7 & 22.3 & & 186.9 & 121.2 \\
\hline
\end{tabular}

protects vulnerable seedlings from exposure to rainfall and wind events that may have increased carrot mortality.

Carrot yield. In 2009, total carrot yield was influenced by compost but not by tillage or cultivar (Table 5). Overall, total yield was $11.6 \%$ higher in compost compared with non-compost treatments (Figure 1). Defectfree yield was affected by the interaction between compost and cultivar (Table 5;
Fig. 1); compost was associated with higher yields for the Canada cultivar but not for 'Finley' or 'Recoleta' (Fig. 1).

In 2010, total yield was influenced by the interaction between cultivar and tillage, but not by compost (Table 5; Fig. 2). For 'Finley', total yield was $22 \%$ higher in ST treatments compared with CT. However, tillage had no effect on total yields of 'Canada' or 'Recoleta'. Defect-free yield was only affected

Table 4. Effects of tillage, variety, and compost on carrot density, 2009 and 2010.

\begin{tabular}{|c|c|c|c|c|c|c|}
\hline \multirow[b]{4}{*}{ Variety } & \multicolumn{6}{|c|}{ Density } \\
\hline & \multicolumn{2}{|c|}{ May } & \multicolumn{2}{|c|}{ June } & \multicolumn{2}{|c|}{ September } \\
\hline & 2009 & 2010 & 2009 & 2010 & 2009 & 2010 \\
\hline & \multicolumn{6}{|c|}{ 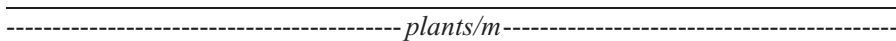 } \\
\hline \multicolumn{7}{|c|}{ Tillage main effect } \\
\hline $\mathrm{CP}$ & 14.9 & 14.1 & 11.8 & 14.2 & 13.0 & $13.5 \mathrm{~A}$ \\
\hline ST & 13.3 & 17.2 & 10.9 & 16.2 & 13.0 & $17.1 \mathrm{~B}$ \\
\hline \multicolumn{7}{|c|}{ Variety main effect } \\
\hline Canada & 13.9 & 15.4 & 11.8 & $15.0 \mathrm{ab}$ & $14.4 \mathrm{a}$ & $16.1 \mathrm{ab}$ \\
\hline Finley & 13.4 & 16.6 & 10.4 & $17.0 \mathrm{a}$ & $11.0 \mathrm{~b}$ & $17.3 \mathrm{a}$ \\
\hline Recoleta & 15.2 & 14.7 & 11.7 & $13.2 \mathrm{~b}$ & $13.6 \mathrm{ab}$ & $12.9 \mathrm{~b}$ \\
\hline Tillage (T) & NS & NS & NS & NS & NS & $\mathrm{z}$ \\
\hline Compost (C) & NS & NS & NS & NS & NS & NS \\
\hline Variety & NS & NS & NS & $\mathrm{z}$ & $*$ & $*$ \\
\hline $\mathrm{T} \times \mathrm{C}$ & NS & NS & NS & NS & NS & NS \\
\hline $\mathrm{T} \times \mathrm{V}$ & NS & $*$ & NS & NS & NS & NS \\
\hline $\mathrm{C} \times \mathrm{V}$ & NS & NS & NS & NS & NS & NS \\
\hline $\mathrm{T} \times \mathrm{C} \times \mathrm{V}$ & NS & NS & NS & NS & NS & NS \\
\hline
\end{tabular}

${ }^{\mathrm{z}} P<0.10$

$* P<0.05 ; * * P<0.01 ; * * * P<0.001 ; \mathrm{NS}=$ nonsignificant.

$\mathrm{CP}=$ chisel plow; $\mathrm{ST}=$ strip tillage.

Within each column, different letters indicate significant differences at $P \leq 0.05$.

Table 5. Significance of effects of tillage, compost, and variety on carrot yield and number, 2009-2010.

\begin{tabular}{|c|c|c|c|c|c|c|c|c|}
\hline & \multicolumn{4}{|c|}{ Yield } & \multicolumn{4}{|c|}{ Number } \\
\hline & \multicolumn{2}{|c|}{ Total } & \multicolumn{2}{|c|}{ Defect-free } & \multicolumn{2}{|c|}{ Total } & \multicolumn{2}{|c|}{ Defect-free } \\
\hline & 2009 & 2010 & 2009 & 2010 & 2009 & 2010 & 2009 & 2010 \\
\hline & ---- & . & . & ---Sig & ince-- & --- & -----" & ----- \\
\hline Tillage (T) & NS & NS & NS & NS & NS & $\mathrm{z}$ & NS & NS \\
\hline Compost (C) & $*$ & NS & $* *$ & NS & NS & NS & NS & NS \\
\hline Variety & NS & $* * *$ & z & $* * *$ & $*$ & $*$ & $* *$ & $\mathrm{z}$ \\
\hline $\mathrm{T} \times \mathrm{C}$ & NS & NS & NS & NS & NS & NS & NS & NS \\
\hline $\mathrm{T} \times \mathrm{V}$ & NS & $\mathrm{z}$ & NS & NS & NS & NS & NS & NS \\
\hline $\mathrm{C} \times \mathrm{V}$ & NS & NS & $\mathrm{z}$ & NS & NS & NS & NS & NS \\
\hline $\mathrm{T} \times \mathrm{C} \times \mathrm{V}$ & NS & NS & NS & NS & NS & NS & NS & NS \\
\hline
\end{tabular}

${ }^{\mathrm{z} P} P<0.10$

$* P<0.05 ; * * P<0.01 ; * * * P<0.001 ;$ NS $=$ nonsignificant.

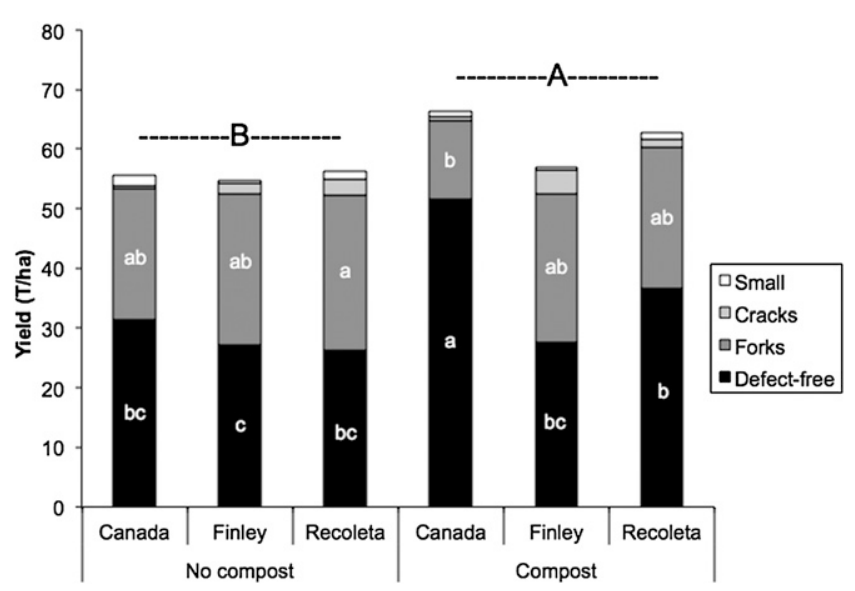

Fig. 1. Effect of cultivar and compost addition on mean carrot yield by category, 2009. Means within the same quality category with common letters are not significantly different (Fisher's least significant difference method; $P=0.05$ ). The main effect of compost on total yields is indicated by capital letters. 
by cultivar; yields of 'Canada' were higher than those for 'Finley' or 'Recoleta'.

Carrot quality. In both years, the percentage of carrot defects (forked, cracked, or undersized carrots) was influenced by cultivar and compost but not by tillage (Table 6). In general, 'Canada' had the lowest percentage of carrots with defects. For example, 'Canada' had a smaller percentage of forked carrots (by number) compared with 'Finley' in 2009 and compared with 'Recoleta' in 2010 (Table 6; Figs. 1 and 2). 'Canada' also had a lower percentage (by both number and weight) of cracked carrots compared with 'Finley' in both years. The large percentage of cracked and forked carrots in the cultivar Finley explains why defect-free yield was often low for this cultivar despite total yields that were equivalent or greater than the other varieties (Figs. 1 and 2). For example, in 2010, 'Finley' had greater total yield than 'Recoleta' but equivalent defect-free yield as a result of a high incidence of cracks and forks.

Compost affected the percentage of forked and small carrots in 2009 as well as the percentage of forked carrots in 2010 but had no effect on the percentage of cracked carrots in either year (Table 6). In 2009, compost reduced the number of forked carrots from $38 \%$ to $30 \%$ and the weight of forked carrots from $45 \%$ to $34 \%$ of total carrot weight (Table 6; Fig. 1). Compost also reduced the number of undersized carrots from $11 \%$ to $6 \%$ and the weight of undersized carrots from $2 \%$ to $1 \%$ of total carrot weight in 2009. In 2010, compost increased the number of forked carrots from $14 \%$ to $17 \%$ but had no detectable effect on the weight of forked carrots as a percentage of total weight (Table 6).

Neither tillage nor compost influenced the root weight, the RSR, or the soluble solid content of defect-free carrots (Table 7). However, the leaf dry weight of 'Finley' was lower than that of the other two varieties, resulting in a higher RSR. We had anticipated that under ST, the presence of the barley cover crop during early carrot growth might influence the RSR as a result of changes in light quality (Smith, 1982) or wind (Goodman and Ennos, 1996). However, our results suggest that when barley growth is ended at a height of 20 to $30 \mathrm{~cm}$, it does not influence long-term carrot growth and root-shoot partitioning.

Effects on weeds. Tillage impacted total weed density in 2009 but not 2010 (Fig. 3AB). In 2009 , total weed density was $73 \%$ higher under CT compared with ST $(P<$ 0.05 ) attributable primarily to the greater prevalence of purslane (Portulaca oleracea) under CT (Fig. 3A). The observed effects of tillage on purslane density in 2009 are consistent with the hypothesis that the emergence of summer annual weeds is reduced in the absence of tillage. Tillage can stimulate germination of many summer annual weeds through several mechanisms including increases in soil nitrate, temperature, or light (Mohler, 2001). In addition, the presence of a barley cover crop in the between-row environment of ST may have inhibited purslane emergence through shading, cooling, or allelopathic effects.

Compost had significant but inconsistent effects on total weed density in 2009 and 2010 (Fig. 3A-B). In 2009, compost reduced weed density in CT treatments but not ST

treatments (Fig. 3A). However, in 2010, compost treatments had higher weed density $(P<0.05)$ than non-compost treatments (Fig. 3B). In part these differences may be explained by variation in weed communities in the two fields where experiments were conducted. Purslane density was very high in 2009 but very low and variable in 2010,

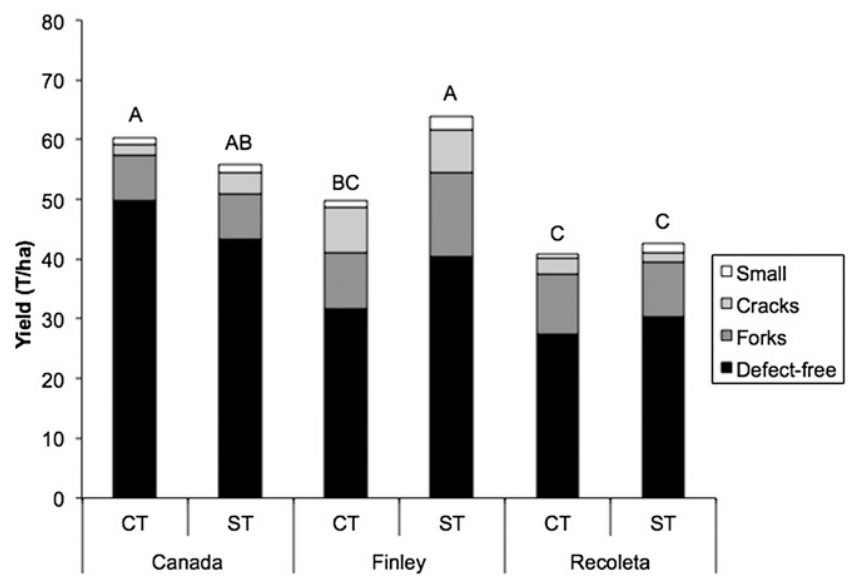

Fig. 2. Effect of cultivar and tillage on mean carrot yield by category, 2010. ST = strip tillage; $\mathrm{CT}=$ conventional tillage. Means of total yield with common letters are not significantly different (Fisher's least significant difference method; $P=0.05$ ). For quality categories, no significant cultivar by tillage interactions were found (Table 5), so no mean separation was performed.

Table 6. Effects of tillage, compost, and variety on carrot quality characteristics, 2009-2010.

\begin{tabular}{|c|c|c|c|c|c|c|c|c|c|c|}
\hline & \multicolumn{5}{|c|}{ Defects by wt (\%) } & \multicolumn{5}{|c|}{ Defects by number $(\%)$} \\
\hline & \multicolumn{2}{|c|}{ Forks } & \multirow{2}{*}{$\frac{\text { Cracks }}{2009-2010}$} & \multicolumn{2}{|c|}{ Small } & \multicolumn{2}{|c|}{ Forks } & \multirow{2}{*}{$\frac{\text { Cracks }}{2009-2010}$} & \multicolumn{2}{|c|}{ Small } \\
\hline & 2009 & 2010 & & 2009 & 2010 & 2009 & 2010 & & 2009 & 2010 \\
\hline \multicolumn{11}{|c|}{ Compost main effect } \\
\hline No compost & $45 \mathrm{~A}$ & 17 & 4 & $2 \mathrm{~A}$ & 3 & $38 \mathrm{~A}$ & $14 \mathrm{~B}$ & 3 & $11 \mathrm{~A}$ & 8 \\
\hline Compost & $34 \mathrm{~B}$ & 22 & 4 & $1 \mathrm{~B}$ & 2 & $30 \mathrm{~B}$ & $17 \mathrm{~A}$ & 3 & $6 \mathrm{~B}$ & 8 \\
\hline \multicolumn{11}{|c|}{ Variety main effect } \\
\hline Canada & 30 & $13 \mathrm{~b}$ & $2 \mathrm{~b}$ & $2 \mathrm{a}$ & 2 & $23 \mathrm{~b}$ & $12 \mathrm{~b}$ & $2 \mathrm{~b}$ & 11 & 8 \\
\hline Finley & 46 & $22 \mathrm{ab}$ & $7 \mathrm{a}$ & $1 \mathrm{~b}$ & 3 & $41 \mathrm{a}$ & $18 \mathrm{ab}$ & $6 \mathrm{a}$ & 7 & 8 \\
\hline Recoleta & 43 & $22 \mathrm{a}$ & $3 \mathrm{ab}$ & $2 a b$ & 3 & $37 \mathrm{ab}$ & $19 \mathrm{a}$ & $3 a b$ & 8 & 8 \\
\hline Tillage $(\mathrm{T})$ & NS & NS & NS & NS & NS & NS & NS & NS & NS & NS \\
\hline Compost (C) & $*$ & NS & NS & $*$ & NS & $\mathrm{z}$ & * & NS & ** & NS \\
\hline Variety (V) & NS & $\mathrm{z}$ & $*$ & $\mathrm{z}$ & NS & $\mathrm{z}$ & $\mathrm{z}$ & $*$ & NS & NS \\
\hline $\mathrm{T} \times \mathrm{C}$ & NS & NS & NS & NS & NS & NS & NS & NS & NS & NS \\
\hline $\mathrm{T} \times \mathrm{V}$ & NS & NS & NS & NS & NS & NS & NS & NS & NS & NS \\
\hline $\mathrm{C} \times \mathrm{V}$ & NS & NS & NS & NS & NS & NS & NS & NS & $\mathrm{z}$ & * \\
\hline $\mathrm{T} \times \mathrm{C} \times \mathrm{V}$ & NS & NS & NS & NS & NS & NS & $\mathrm{z}$ & NS & NS & NS \\
\hline
\end{tabular}

${ }^{\mathrm{z} P}<0.10$

$* P<0.05 ; * * P<0.01 ; * * * P<0.001 ;$ Ns nonsignificant.

Within each column, different letters indicate significant differences at $P \leq 0.05$.

Table 7. Mean root dry weight, shoot dry weight, root-shoot ratio (RSR), and soluble solids (SC). ${ }^{\mathrm{z}}$

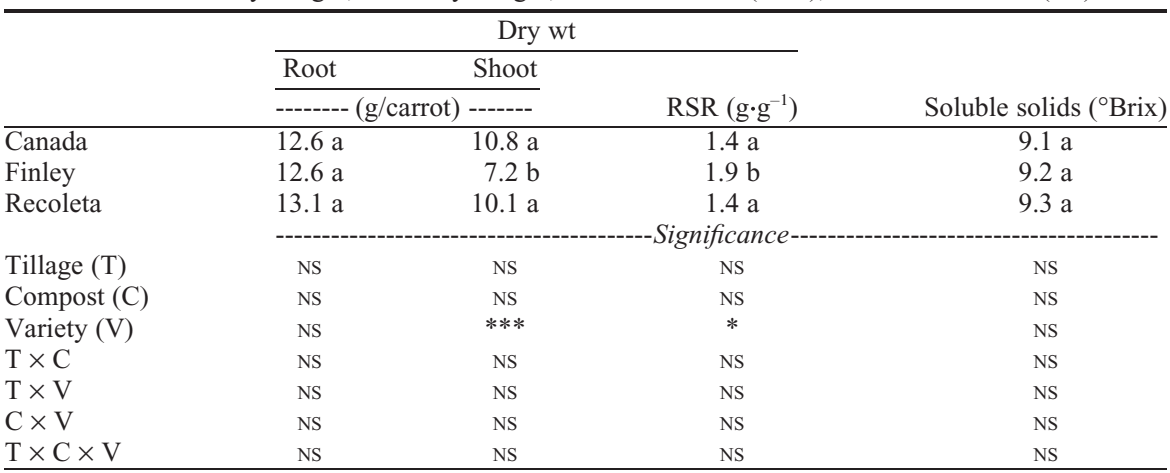

${ }^{2}$ Data were combined by year.

$* P<0.05 ; * * P<0.01 ; * * * P<0.001 ;$ NS $=$ nonsignificant.

Within each column, different letters indicate significant differences at $P \leq 0.05$. 

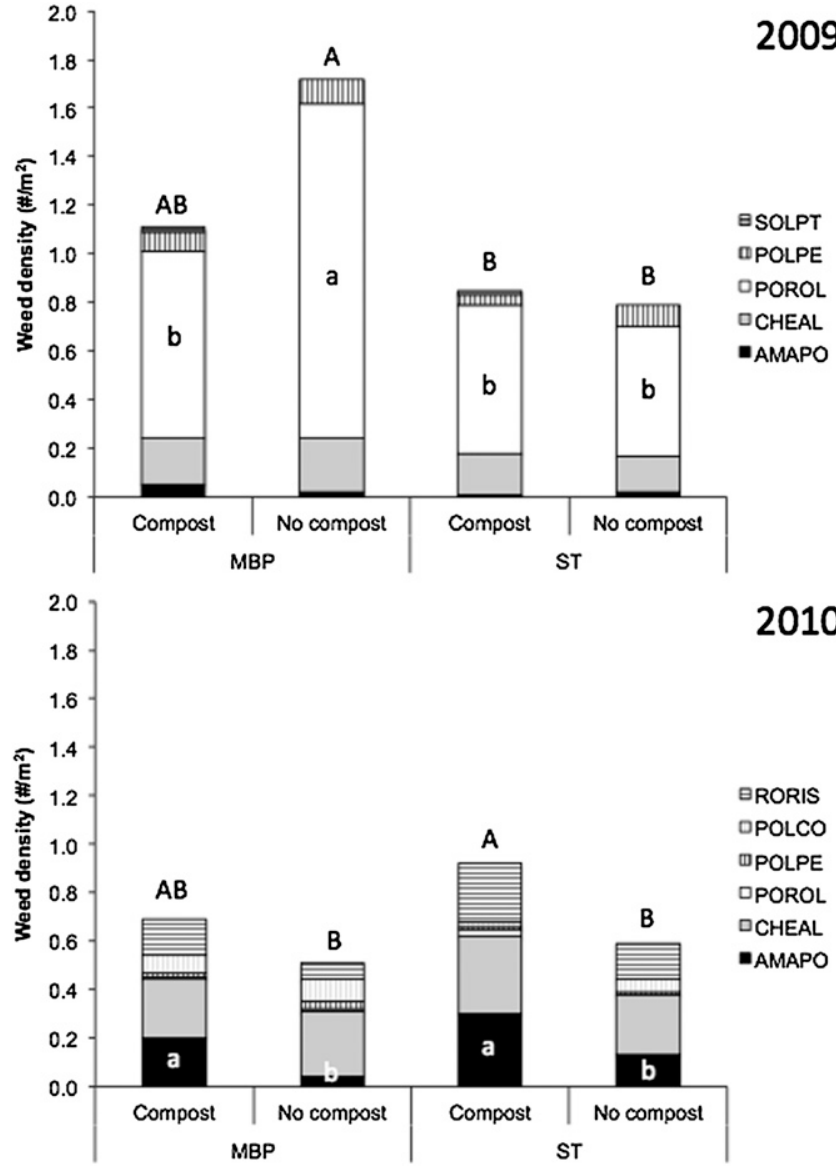

Fig. 3. Effect of tillage and compost on mean weed density by species, 2009 and 2010. Species codes are AMAPO $=$ Amaranthus powellii $($ Powell amaranth); CHEAL $=$ Chenopodium album (common lambsquarters); $\mathrm{POROL}=$ Portulaca oleracea $($ common purslane $) ; \mathrm{POLPE}=$ Polygonum persicaria (ladysthumb); POLCO = Polygonum convolvulus (wild buckwheat); RORIS = Rorippa islandica (marsh yellowcress). For each species, treatment means with common letters are not significantly different (Fisher's least significant difference method; $P=0.05$ ). For mean total weed density, capital letters are used to specify significance.

whereas Powell amaranth density was high in 2010 but very low and variable in 2009 . Therefore, the compost-mediated reductions in total weed density observed in 2009 were attributable primarily to effects on purslane (Fig. 3), whereas those observed in 2010 were attributable primarily to effects on Powell amaranth (Fig. 3). In cases in which weed density was low and variable, the statistical power to detect treatment differences was low, so assessment of treatment effects on purslane and Powell amaranth was only possible in 1 year of the study.

The most dramatic effect of compost on weed density was observed for Powell amaranth in 2010. In particular, Powell amaranth density was threefold higher where compost was applied. In contrast, compost reduced density of purslane in 2009. Menalled et al. (2005) observed inhibition of emergence of several weed species by high rates ( 8 to $-24 \mathrm{t} \cdot \mathrm{ha}^{-1}$ ) of compost under greenhouse conditions. However, under field conditions at lower application rates $\left(4\right.$ to $\left.8 \mathrm{t} \cdot \mathrm{ha}^{-1}\right)$ compost had no effect on weed emergence (Menalled et al., 2002).

Estimated returns. In 2009, estimated gross returns were influenced by compost but not by tillage or cultivar (Table 8 ). Higher gross returns in compost treatments reflected both higher total yields (Table 5; Fig. 1) and a lower percentage of forked carrots (Table 6) going to the lower price carrot bait market. As a result of the cost of compost, higher gross returns in compost treatments in 2009 did not translate into higher net returns (Table 8). Under our baseline assumptions, increased revenues generated in compost treatments were offset by the cost of compost, which was estimated to be $\$ 150 /$ including transport and application costs. It should be noted, however, that if compost could be attained and spread at lower cost, net revenues would have increased. For example, if the cost of compost were $\$ 100 / t$, net revenues would have been $\$ 426 /$ ha higher under compost than non-compost treatments in 2009.

In 2010, estimates of both gross and net returns were affected by cultivar and tillage but not by compost (Table 8). Net returns were highest for the cultivar Canada (\$1291/ha) and lowest for the cultivar Recoleta ( $\$ 435 / \mathrm{ha})$ as a result of both higher total yield and a higher percentage of defect-free carrots for 'Canada' (Fig. 2). For 'Finley', estimated net returns were higher under ST $(\$ 1572 / \mathrm{ha})$ than under
CT $(\$ 139 / \mathrm{ha})$ as a result of the combined effects of higher yields (Fig. 2) and lower costs under ST.

Estimates of net returns are sensitive to underlying assumptions, particularly those related to the cost of compost and the relative price of cull carrots destined for the deer bait market. For example, if the deer bait market collapsed, as can happen with changes in legislation related to deer baiting (Beversluis, 2008), then estimated net returns in all treatments would have been negative with the exception of compost applied to the cultivar Canada. Conversely, increased demand for deer bait and higher cull market prices would shift economic incentives away from practicesincluding compost applications - that may reduce the percentage of carrot culls.

\section{Summary and Conclusion}

This study demonstrates that ST and compost can improve carrot quality (Table 6) and yield (Table 5). However, the nature and extent of those effects differed with carrot cultivar and year. In 2009, compost improved carrot quality and yield, but tillage had no detectable impact on either. In contrast, in 2010, compost had few significant effects on carrots, but ST reduced carrot seedling mortality and improved yield of the cultivar Finley. Impacts of tillage and compost on weeds also differed by year with ST resulting in equivalent or lower densities of common purslane and compost resulting in equivalent or higher densities of Powell amaranth.

The mechanisms by which compost and tillage affected carrots and weeds in this study are not clear. Compost may improve plant growth through a variety of mechanisms including relieving nutrient constraints, improving soil moisture retention, or reducing the incidence or impact of pests (Roe, 2001) Given synthetic fertilizer application rates and initial soil nutrient levels used in this study, it is unlikely that $\mathrm{N}, \mathrm{P}, \mathrm{K}, \mathrm{Ca}$, or $\mathrm{Mg}$ were limiting for carrots in non-compost treatments (Warncke et al., 2004). Therefore, observed yield and quality benefits from compost in 2009 were unlikely to have been the result of changes in the quantity of these nutrients. However, it is possible that changes in the timing of $\mathrm{N}$ release in response to compost or tillage treatments may have influenced weed or carrot emergence and growth. For example, compost and tillage may influence rates of mineralization through shifts in soil moisture, oxygen, and carbon content. Changes in both the rate and timing of $\mathrm{N}$ release can influence germination of weeds including Powell amaranth (Brainard et al., 2006) and growth and quality of carrots (Batra and Kalloo, 1990; Bienz, 1965). Alternatively, both compost and tillage may have indirectly influenced carrots and weeds through effects on parasitic nematodes (Bird, 1977; Holmstrom et al., 2008; Widmer et al., 2002), pathogens (Douds et al., 1997), or phytotoxic compounds including phenols (Ligneau and Watt, 1995) that may influence emergence and growth of both crops and weeds (Kumar et al., 2008; 
Table 8. Estimated gross and net returns from compost and strip tillage, 2009 and 2010.

\begin{tabular}{|c|c|c|c|c|}
\hline & \multicolumn{2}{|c|}{ Gross returns ${ }^{z}$} & \multicolumn{2}{|c|}{ Net returns ${ }^{\mathrm{y}}$} \\
\hline & 2009 & 2010 & 2009 & 2010 \\
\hline & ------ & ------- & ------ & -------- \\
\hline \multicolumn{5}{|c|}{ Compost main effect } \\
\hline No compost & $4878 \mathrm{a}$ & 5005 & 1118 & 509 \\
\hline Compost & $5613 \mathrm{~b}$ & 4741 & 832 & 698 \\
\hline \multicolumn{5}{|l|}{ Variety $\times$ tillage } \\
\hline \multicolumn{5}{|l|}{ Canada } \\
\hline $\mathrm{CT}$ & 5756 & $5777 \mathrm{a}$ & 1425 & $1446 \mathrm{a}$ \\
\hline ST & 5480 & $5348 \mathrm{a}$ & 1269 & $1136 \mathrm{a}$ \\
\hline \multicolumn{5}{|l|}{ Finley } \\
\hline $\mathrm{CT}$ & 4761 & $4471 \mathrm{bc}$ & 430 & $139 \mathrm{bc}$ \\
\hline ST & 4990 & $5783 \mathrm{a}$ & 780 & $1572 \mathrm{a}$ \\
\hline \multicolumn{5}{|l|}{ Recoletta } \\
\hline $\mathrm{CT}$ & 5445 & $3779 \mathrm{c}$ & 1114 & $-552 \mathrm{c}$ \\
\hline ST & 5041 & $3892 \mathrm{c}$ & 830 & $-318 c$ \\
\hline Tillage (T) & NS & NS & NS & NS \\
\hline Compost (C) & $*$ & NS & NS & NS \\
\hline Variety (V) & NS & $*$ & NS & $*$ \\
\hline $\mathrm{T} \times \mathrm{C}$ & NS & NS & NS & NS \\
\hline $\mathrm{T} \times \mathrm{V}$ & NS & $\mathrm{x}$ & NS & $\mathrm{x}$ \\
\hline $\mathrm{C} \times \mathrm{V}$ & NS & NS & NS & NS \\
\hline $\mathrm{T} \times \mathrm{C} \times \mathrm{V}$ & NS & NS & NS & NS \\
\hline
\end{tabular}

${ }^{\mathrm{z}}$ Gross returns $(\mathrm{GR})=($ defect-free yield $\times$ defect-free price $)+($ cull yield $\times$ cull price $)$.

${ }^{y}$ Net returns $(\mathrm{NR})=\mathrm{GR}-($ total variable costs $)$.

${ }^{\mathrm{x}} P<0.10$.

$* P<0.05 ; * * P<0.01 ; * * * P<0.001 ;$ NS $=$ nonsignificant.

$\mathrm{CT}=$ conventional tillage; $\mathrm{ST}=$ strip tillage.

See methods for details regarding assumptions.

Within each column, different letters indicate significant differences at $P \leq 0.05$.

Menalled et al., 2005). Among these, effects of compost on parasitic nematodes are best known for their effects determining carrot quality characteristics including forks (Abawi and Widmer, 2000; Bird, 1977; Widmer et al., 2002). More information on the mechanisms by which compost and tillage impact carrots and weeds would be useful for optimizing their use in carrot production systems.

Partial budget analysis demonstrated that improvements in yield and quality resulting from compost applications do not necessarily translate into increased net returns. Under our baseline assumptions, increases in gross returns were offset by increased costs associated with compost production, transport, and application. However, economic estimates depend critically on assumptions regarding the costs of compost and tillage as well as the relative prices of different carrot markets. In particular, legislatively driven volatility in the market for carrots as deer bait can result in large swings in the value of cull carrots (Beversluis, 2008). Without such alternative markets, practices that reduce the percentage of cull carrots - including compost application-are likely to be of increasing importance for maintaining profitability.

Beyond the short-term economic benefits of ST and compost, both practices can result in increases in SOM and associated improvements in physical, chemical, and biological characteristics of soils that may improve yields and profits in rotational crops. Long-term studies examining the cumulative effect of compost and tillage practices are needed before their impact on agro-ecosystems can be fully assessed.

\section{Literature Cited}

Abawi, G.S. and T.L. Widmer. 2000. Impact of soil health management practices on soilborne pathogens, nematodes and root diseases of vegetable crops. Appl. Soil Ecol. 15:37-47.

Batra, B.R. and G. Kalloo. 1990. Effect of different levels of irrigation and fertilization on growth and yield of carrot (Daucus carota $\mathrm{L}$.) for root production. Veg. Sci. 17:127-139.

Beversluis, B. 2008. Michigan's ban on deer baiting costly even before the hunting season begins. Grand Rapids Press. 14 Sept. <http://www. michigan-sportsman.com/forum/showthread. php?t=251342>.

Bienz, D.R. 1965. Carrot splitting and second growth in central Washington as influenced by spacing, time of side-dressing and other cultural practices. Proc. Amer. Soc. Hort. Sci. 86:406-410.

Bird, G.W. 1977. Population dynamics of Pratylenchus penetrans associated with 3 cultivars of Solanum tuberosum. J. Nematol. 9:265 (Abstract).

Brainard, D.C., A. DiTommaso, and C.L. Mohler. 2006. Intraspecific variation in germination response to ammonium nitrate of Amaranthus powellii originating from organic versus conventional vegetable farms. Weed Sci. 54:435442.

Brainard, D.C., E. Haramoto, and D. Noyes. 2012. Tillage and cover crop effects on weed management in snap beans. Abstract no. 57. Weed Science Society of America Annual Meeting, Waikoloa, HA.

Dartt, B., B.J. Roy, J. Breinling, and V. Morrone. 2002. Costs of processing carrot production in West Central Michigan. Michigan State University, Department of Ag., Food and Res. Economics Series Staff Paper 11687. 9 Apr. 2012. <http://ideas.repec.org/p/ags/midasp/ 11687.html>.
Douds, D.D., L. Galvez, M. Franke-Snyder, C. Reider, and L.E. Drinkwater. 1997. Effect of compost addition and crop rotation point upon VAM fungi. Agr. Ecosyst. Environ. 65: 257-266.

ERS/USDA. 2011. U.S. carrot statistics. Table 12. MI carrots, fresh market and processing, 1960-2009. $<$ http://usda.mannlib.cornell.edu/MannUsda/ viewDocumentInfo.do?documentID=1577>.

Goodman, A.M. and A.R. Ennos. 1996. A comparative study of the response of the roots and shoots of sunflower and maize to mechanical stimulation. J. Expt. Bot. 47:1499-1507.

Holmstrom, D., K. Sanderson, and J. Kimpinski. 2008. Effect of tillage regimens on soil erosion, nematodes, and carrot yield in Prince Edward Island. J. Soil Water Conserv. 63: 322-328.

Kumar, V., D.C. Brainard, and R.R. Bellinder. 2008. Suppression of Powell amaranth ( $\mathrm{Ama}$ ranthus powellii), shepherd's-purse (Capsella bursa-pastoris), and corn chamomile (Anthemis arvensis) by buckwheat residues: Role of nitrogen and fungal pathogens. Weed Sci. 56: 271-280.

Liebman, M. and C.L. Mohler. 2001. Weeds and the soil environment, p. 210-268. In: Liebman, M., C.L. Mohler, and C.P. Staver (eds.). Ecological management of agricultural weeds. Cambridge University Press, Cambridge, UK.

Ligneau, L.A. and T.A. Watt. 1995. The effects of domestic compost upon the germination and emergence of barley and six arable weeds. Ann. Appl. Biol. 126:153-162.

Luna, J. and M. Staben. 2002. Using strip tillage in vegetable production systems in Western Oregon. Oregon State University Extension Service Publication: EM 8824.

Luna, J.M., J.P. Mitchell, and A. Shrestha. 2012. Conservation tillage in organic agriculture: Evolution toward hybrid systems. Renew. Agr. and Food Syst. (in press).

Magdoff, F. and H. van Es. 2000. Building soils for better crops. $2^{\text {nd }}$ Ed. Sustainable Agriculture Publications, University of Vermont, Burlington, VT.

Masabni, J.G. and B.H. Zandstra. 1999. Discovery of a common purslane (Portulaca oleracea) biotype resistant to linuron. Weed Technol. 13: 599-605.

McNaughton, K.E., J. Letarte, E.A. Lee, and F.J. Tardif. 2005. Mutations in ALS confer herbicide resistance in redroot pigweed (Amaranthus retroflexus) and Powell amaranth (Amaranthus powellii). Weed Sci. 53:17-22.

Menalled, F.B., D.D. Buhler, and M. Liebman. 2005. Composted swine manure effects on germination and early growth of crop and weed species under greenhouse conditions. Weed Technol. 19:784-789.

Menalled, F.B., M. Leibman, and D. Buhler. 2002. Impact of composted swine manure on crop and weed establishment and growth. Proc. of the Fifth Workshop of the European Weed Research Society on Physical and Cultural Weed Control. Pisa, Italy. p. 183.

Mochizuki, M.J., A. Rangarajan, R.R. Bellinder, T. Björkman, and H.M. van Es. 2007. Overcoming compaction limitations on cabbage growth and yield in the transition to reduced tillage. HortScience 42:1690-1694.

Mohler, C.L. 2001. Mechanical management of weeds, p. 139-209. In: Liebman, M., C.L. Mohler, and C.P. Staver (eds.). Ecological management of agricultural weeds. Cambridge University Press, New York, NY.

Roe, N.E. 2001. Compost effects on crop growth and yield in commercial vegetable production 
systems, p. 123-133. In: Stoffella, P.J. and B.A. Kahn (eds.). Compost utilization and horticultural cropping systems. CRC Press, Boca Raton, FL.

Sanchez, E.S. and T.L. Richard. 2009. Using organic nutrient sources. Penn State Agricultural Research and Cooperative Extension Publication. 20 Feb. 2012. <http://pubs.cas.psu.edu/ FreePubs/pdfs/uj256.pdf $>$.

SAS Institute. 2009. SAS user's guide: Statistics. The SAS Institute Inc., Cary, NC.
Smith, H. 1982. Light quality, photoreception and plant strategy. Annu. Rev. Plant Physiol. 33:481518.

Stein, D. 2011. 2011 Custom machine and work rate estimates. Michigan State University Extension, MI

Teasdale, J.R. 1998. Cover crops, smother plants, and weed management, p. 247-270. In: Hatfield, J.L., D.D. Buhler, and B.A. Stewart (eds.). Integrated weed and soil management. Ann Arbor Press, Chelsea, MI.
Warncke, D., J. Dahl, and B. Zandstra. 2004. Nutrient recommendations for Michigan vegetable crops. MSU Extension Bulletin Publication E2934. East Lansing, MI.

Widmer, T.L., N.A. Mitkowski, and G.S. Abawi. 2002. Soil organic matter and management of plant-parasitic nematodes. J. Nematol. 34:289295.

Zhu, S., J.R. Mount, and J.L. Collins. 1992. Sugar and soluble solid changes in refridgerated sweet corn (Zea mays L). J. Food Sci. 57:454- 457. 